ISSN 2078-6441. Вісник Львівського університету. Серія географічна. 2014. Випуск 47. С. 68-77. Visnyk of the Lviv University. Series Geography. 2014. Issue 47. P. 68-77.

504.064.3:574[504.3.054:551.578.4](477.86)

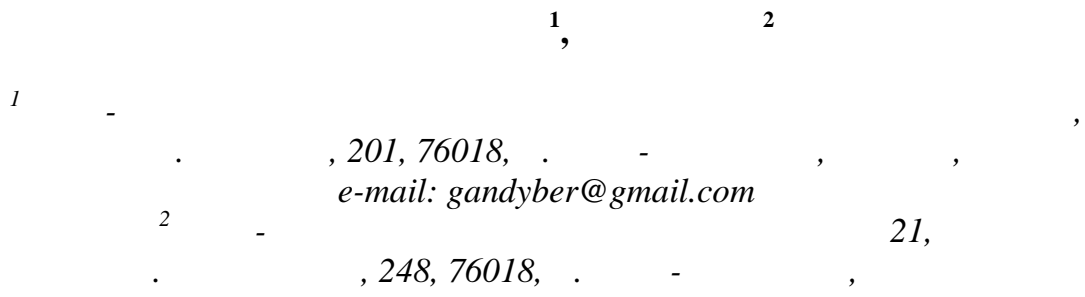

осліджено фізичні вл стивості пилув тих вип д нь н сніговий покрив у ередк рп тті. вис тмосферного пилу у сніговій воді про н лізов но методом нефелометрії. цінку вл стивостей пилу викон но з дин мікою осід ння ч сток з вису у сніговій воді. ні опр цьов но метод ми кореляційно-регресійного, дисперсійного т еколого-геохімічного н лізу. 'ясов но, що $12 \%$ дослідженої території перебув є в умов х регіон льного природного фону, більше третини - в умов х техногенного з бруднення, половин - в умов х техногенного фону.

лючові слов : з порошення тмосферного повітря, моніторинг довкілля, обстеження снігу, техногенне з бруднення.

жливими з вд ннями екологічного моніторингу довкілля є ді гностик т оцінк просторового розподілу первинних техногенних тмосферних вип д нь. сновними особливостями т ких вип д нь $є з б$ г чення в жкими елемент ми т м л розчинність [2]. пр ктиці ч сто виник є потреб оконтурити т оцінити інтенсивність техногенних вип д нь н тлі природних. р диційно це вирішують через поліелементний хімічний н ліз тмосферних вип д нь бо компонентів довкілля, які їх н гром джують, - грунту, рослинності, снігового покриву тощо [2]. кий н ліз потребує зн чних п р турних т ресурсних витр т. одноч с ді гностув ння т оконтурюв ння первинних техногенних вип д нь доцільно проводити із з стосув нням будь-яких доступних методів 3 умови, що вони грунтуються н ключових п р метр х первинних вип д нь техногенних тмосферних домішок і д ють змогу оконтурити поля з бруднення.

сновним компонентом тмосферних вип д нь є пил. ехногенн скл дов пилу, 3 звич й, ст новить 5-10\% від його з г льного з п су в тмосфері, співвідношення природної т техногенної скл дових є дин мічним як 3 кількістю, т к і 3 фізикохімічними вл стивостями $[1,2] .3$ п р метрів пилу, здебільшого, оцінюють його кількість, рідше хімічний скл д. ш мет - розробк т проб ція способу ді гностики 3 фізичними п р метр ми техногенного тмосферного пилу, н гром дженого у сніговому покриві.

ідбір проб снігу викон но протягом лютого 2013 р. н 63 пікет х, орг нізов них у вигляді двох тр нсект, що проходять через в но- $\mathrm{p}$ нківську обл. у субширотному т субмериді н льному н прям х, перетин ючись в обл сному центрі. ршрути спостережень проляг ли із м. в но- р нківськ у чотирьох керунк х (перер хов но згідно з черговістю викон ння спостережень): н північ ( ог тинський керунок);

(C) НЖ ., НЖ ., 2014 
н 3 хід ( олехівський керунок); н південь ( орохтянський керунок), тут мереж спостережень сяг є уковеля; н схід ( ороденківський керунок).

пікет х циліндричним пл стм совим пробовідбірником відбир ли проби снігового покриву н товщину леж ння. кожному пікеті робили в середньому по 17 уколів снігу, із яких формув ли зміш ну пробу. л бор торних умов х сніг розтоплюв ли т вимірюв ли об'єм снігової води. воді вимірюв ли к л мутність нефелометричним методом 3 використ нням прил ду контролю якості води U-10 (Horiba). езульт ти н ведено у нефелометричних одиницях к л мутності ( ). имірюв ння викон но з точністю 1 у ді п зоні від 0 до $800 \quad 3$ збіжності $\pm 3 \%$ від виміряного результ ту. л мутність дистильов ної води - 0 . ожну пробу снігової води вимірюв ли послідовно у сім ет пів з інтерв лом 2 хв. кожному ет пі проби вимірюв ли щосекунди від 15 до 28 р зів. тже, снігову воду з місць спостережень вимірюв ли у середньому 170 р зів протягом 20 хв.

бчислення вибіркового середнього результ тів вимірюв нь, середнього кв дp тичного відхилення, дисперсії, т кож дисперсійний т кореляційно-регресійний н лізи проводили з використ нням функцій Microsoft Excel. ході кореляційного н лізу обчислено коефіцієнт детермін ції $R^{2}$.

ля оцінки фізичних вл стивостей з вису окремих проб снігової води обчислюв ли дисперсію середнього зн чення ( $)$ т коефіцієнт детермін ції лінійної регресії, що описує зв'язок між зн ченням $\quad$ т ч сом вимірюв ння $(R)$. вимірюв ння з стосов но як критерій оцінки дин міки осід ння з вису. рім того, для кожної проби підібр но тип регресії, з допомогою якого процес описують із н йбільшим зн ченням коефіцієнт детермін ції.

метою опосередков ного оцінюв ння густини вип д нь пилу н поверхню у місцях спостережень обчислюв ли пок зник пропорційності $\quad(\quad)$ :

$$
=\quad \times T^{-1} \times S^{-1}
$$

де 1 - усереднене зн чення к л мутності 3 результ т ми вимірюв нь першого ет пу; $T$ - трив лість леж ння снігового покриву після, діб; $S$ - площ , м² $^{2}$.

ефелометричний пок зник неоднорідності з вису у сніговій воді ( седимент) обчислюв ли з формулою

$$
\text { седимент, } \%=\left(\begin{array}{cc}
1- & i
\end{array}\right) \times \quad I^{-1} \times 100,
$$

де $1-$ усереднене зн чення к л мутності 3 результ т ми вимірюв нь першого ет пу; $\quad i-$ зн чення к л мутності $i$-го вимірюв ння (у цьому дослідженні сьомого).

ормов не відхилення від середнього визн ч ли з формулою [3]

$$
t=\frac{\left(x_{i}-\bar{x}\right)}{s_{x}},
$$

де $x_{i}-$ вибірков в рі нт ; $x_{i}-$ вибіркове середнє; $s_{x}-$ ст нд ртне відхилення.

сі ст тистичні пок зники т оцінку невизн ченості обчислено для рівня вірогідності 0,95 . он досліджув ного п р метр визн ч ли з рівнянням [6]

$$
X_{\phi}=\operatorname{ant} \lg \left(\overline{\lg X_{i}}\right),
$$

де $X_{\Phi}-$ зн чення фону п р метр ; $\overline{\lg X_{i}}=\frac{1}{N} \sum_{i=1}^{N} \lg X_{i}$ - середній лог рифм виміряних зн чень п р метр норм лізов ної вибірки; $N$ - розмір вибірки. 
інім льні ном льні від’ємні відхилення від фону обчислюв ли з формулою [6]

$$
C_{a}=X_{\Phi} \times \varepsilon^{-1},
$$

де $\varepsilon=$ ant $\lg \sigma_{\mathrm{lg}}-$ ст нд ртний множник $\left(\sigma_{\mathrm{lg}}-\right.$ середнє кв др тичне відхилення лог рифмів зн чень досліджув ного п р метр ).

критерій ном льності п р метрів з вису у сніговій воді прийм ли трир зове перевищення коефіцієнт концентр ції $\left({ }_{c}\right)$ щодо місцевого фону досліджув ного п р метр $\left(C_{\phi}\right)$. н чення ${ }_{c}$ обчислюв ли т к [6]:

де $C_{i}$ - концентр ція речовини н пікеті.

$$
{ }_{c}=C_{i} \times C_{\phi}^{-1}
$$

гідно з рекоменд ціями $[4,5]$, обчислюв ли межу основної невизн ченості спостережень, що охоплює скл дові з основною похибкою з собів вимірюв нь, вип дкову ст тистичну похибку вимірюв ння т ст новить $11 \%$.

результ т ми вивчення ст ну снігового покриву н пікет х (товщин, густин, н явність н сту, перекритого свіжим снігом), спостереженнями $з$ погодою т н лізом д них інтернет-ресурсу Meteo.ua (http://meteo.ua/ua) з період від грудня 2012 p. визн чено ч с леж ння снігу в місцях відбору. 5 пікет х сніговий покрив до відбору проб леж в 2 доби, ще н 5 - 45 діб, н 53 - від 9 до 20. н ліз н прямів вітру до моменту відбору проб з свідчив, що викиди основних джерел емісії потр пили н всі місця спостережень. цьому р зі чинником збільшення невизн ченості результ тів 3 опосередков ної оцінки густини тмосферних вип д нь пилу (формул (1)) є ч с леж ння снігу. ля оцінки фізичних п р метрів з вису у сніговій воді ост нній чинник не м є зн чення.

ослідженнями виявлено зн чну в рі бельність ст тистичних п р метрів к л мутності снігової води як з пок зником пропорційності , т к і з неоднорідністю фізичних п р метрів з вису ( $\quad$ седимент, $R$ ) (т бл. 1$)$.

блиця 1

р метри к л мутності снігової води у місцях спостережень

\begin{tabular}{|c|c|c|}
\hline р метр & ереднє & исперсія \\
\hline & 11 & 592 \\
\hline & 225 & $394 \times 10^{3}$ \\
\hline седименш $\%$ & 29 & 145 \\
\hline$R$ & 0,59 & 0,07 \\
\hline
\end{tabular}

іж опосередков ною кількісною х р ктеристикою пилув тих тмосферних вип д нь ( ) і т ким пок зником фізичних вл стивостей з вису у сніговій воді, як , простежується середньої сили нелінійний зв'язок при $R^{2}=0,69$. лежність проксимов но ступеневою регресією (див. рис. 1). жливою х р ктеристикою фізичних вл стивостей снігової води є дин мік осід ння з вису (ст тистичний зв'язок зн чення

із ч сом осід ння), як виявил суттєву відмінність зв'язку н зв них п р метрів 3 різних умов техногенного н в нт ження - від цілковитої відсутності до тісного зв' язку при $R^{2}=0,98$ (середнє т дисперсія $R \quad$ н ведені у т бл. 1). кі ст тистичні п р метри осід ння з вису т їхній зв'язок із пок зником пропорційності свідч ть про якісні зміни фізико-хімічних вл стивостей i, відповідно, зрост ння густини пилу, що седиментується н поверхню у місцях спостережень 3 різним техногенним н в нт женням. 


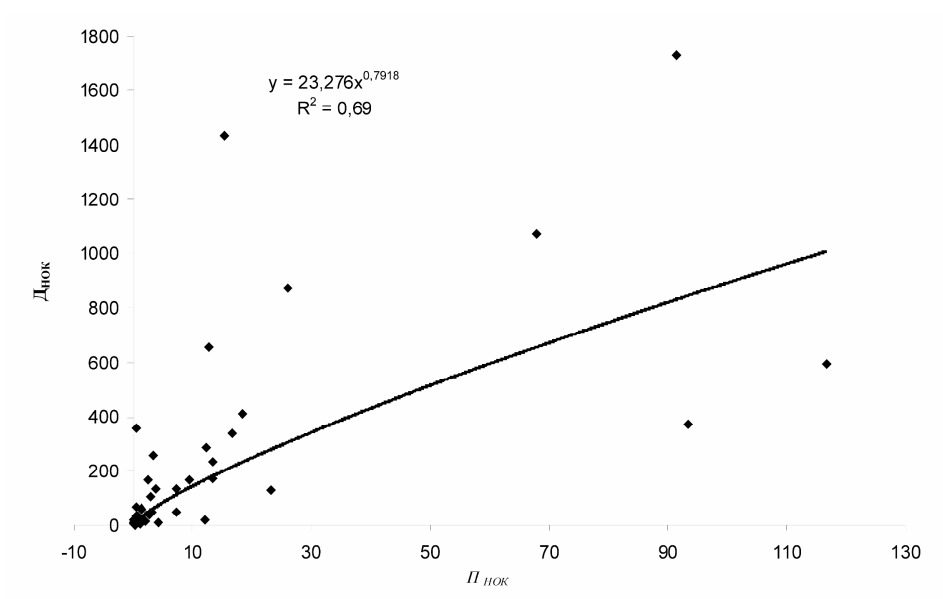

ис. 1. в'язок між зн ченням опосередков ної оцінки вип д нь пилу

н сніг ( ) т дисперсією під ч с осід ння з вису

н ліз просторового розподілу зн чення

з свідчує, що н йбільш різном нітність фізичних вл стивостей пилув тих тмосферних вип д нь пов'яз н 3 потужними полями з порошення приземного ш ру повітря, які сформув лись н півночі в но- $\mathrm{p}$ нківської обл. $з$ урбоекосистеми в но- $\mathrm{p}$ нківськ, цементно-шиферного виробництв у с. мниця т, передусім, урштинської і н з хідному н прямі спостережень - у зв'язку з промисловим комплексом м. луш (див. рис. 2). н чення седимент не корелює зі зн ченнями т дисперсії в р зі осід ння з вису у сніговій воді. собливість пок зник неоднорідності з вису у сніговій воді поляг є в тому, що він д є змогу оцінити контр стність бо їі відсутність у фізичних вл стивостях суміші пилув тих ч сток, седиментов них н снігову поверхню 3 тмосферного повітря. орівняння особливостей просторового розподілу зн чень т седимент доводить, що Зн чення седимент, н прикл д, в умов $\mathrm{x}$ регіон льного природного фону тмосферних вип д нь, різко збільшується 3 н йнижчих зн чень . е с ме простежується й н східному н прямі спостережень, де у формув нні тмосферних домішок не беруть уч сті великі промислові джерел емісії. одібн ситу ція озн ч $є$, що в суміші зерен пилу є незн чн кількість речовини зі зн чно більшою густиною, н прикл д, н фоні будівельного, сільськогоспод рського бо природного пилу тр нспортний, що утворюється вн слідок тертя мет левих дет лей втомобілів.

ведені д ні свідч ть про декільк типів з порошення приземного ш ру повітря н території в но- р нківської обл., які можн кл сифікув ти з ст тистичними п р метр ми осід ння з вису у сніговій воді. ля перевірки гіпотези про однорідність результ тів спостережень і виявлення д них, що можуть н леж ти до різних типів з порошення, з стосов но процедуру н лізу, як охоплюв л : 1) перевірку д них щодо однорідності $3 \quad t$-критерієм (формул (3)); 2) перевірку утворених після першої процедури вибірок щодо однорідності з зн ченням коефіцієнт концентр ції (формул (6)); 3) виділення 3 критерієм ном льності $\left(x_{i}<C_{A}\right.$, формул (5)) із вибірки 3 н йменшим середнім сукупності д них, які прийм ють як т кі, що описують місцевий природний фон. 


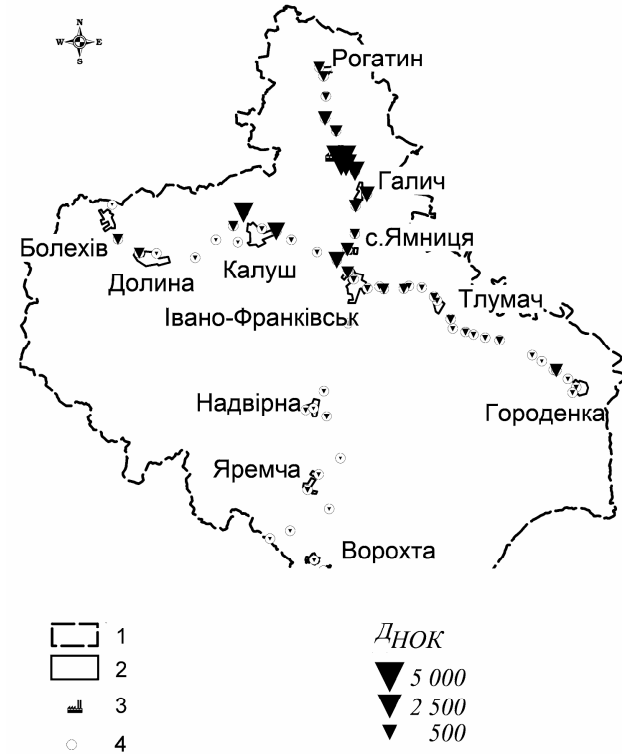

пок зник неоднорідності з вису (б) н досліджув ній території. н чення

н ведено у лог рифмічній шк лі: 1 - контур обл сті; 2 - н селені пункти;

$$
3 \text { - урштинськ ; } 4 \text { - місця спостережень }
$$

опис ною вище процедурою перевірено б зові вибірки зн чень п р метрів , седимен,,$R$, утворені згідно з умов ми техногенезу. зові вибірки згідно з

т розділено кожну н чотири вибірки. скільки зимові пилув ті вип д ння з тмосфери в регіоні $є$ перев жно техногенними, то вибірки, зроблені $з$ озн кою густини вип д нь і п р метрів осід ння з вису у сніговій воді, ми вв ж ємо т кими, що відповід ють умов м техногенезу в місцях спостережень. отири утворені вибірки умовно н зв но зон ми (див. т бл. 2, рис. 3): критичного техногенного з бруднення приземного ш ру повітря ( ); техногенного з бруднення ( ); техногенного фону ( ); природного фону ( ).

блиця 2

цінк збіжності пікетів з зн ченнями т

т відносний розподіл з рівнями з бруднення снігової води

\begin{tabular}{|c|c|c|c|c|}
\hline р метри & & & & \\
\hline біжність, \% & 68 & 80 & 67 & 91 \\
\hline $\begin{array}{c}\text { середнен 3 т } \\
\text { ч стк пікетів, \% }\end{array}$ & 12 & 53 & 19 & 16 \\
\hline
\end{tabular}

еревірк щодо збіжності утворених з п р метр ми $\mathrm{T}$

вибірок з свідчил н йбільшу подібність переліку пікетів із зони критичного з бруднення і техногенного фону, збіжність - 91 т $80 \%$, відповідно. еншу подібність м ють вибірки зони техногенного з бруднення т природного фону (див. т бл. 2). ізниця збіжності 
утворил ся вн слідок того, що у вип дку $\quad$ т $\quad$ згрупув лись пікети під впливом порівняно однотипних джерел тмосферної емісії (у зоні впливу урштинської т

луської ) т місця фонового з бруднення, перев жно від втодоріг.

енш збіжність вибірок, віднесених до умов техногенного з бруднення т природного фону, зумовлен тим, що в першому вип дку об'єдн но місця під впливом середньої т м лих потужностей джерел тмосферної емісії різного типу техногенних об’єктів, від яких утворюється різний з фізичними вл стивостями пил. прикл д, місць видобутку н фти, деревообробних підприємств, урбол ндш фтів тощо. ід м ркою природного фону об'єдн но пікети, що перебув ють під сл бким впливом різнорідних джерел тмосферної емісії-як місцевих, т к і регіон льних.

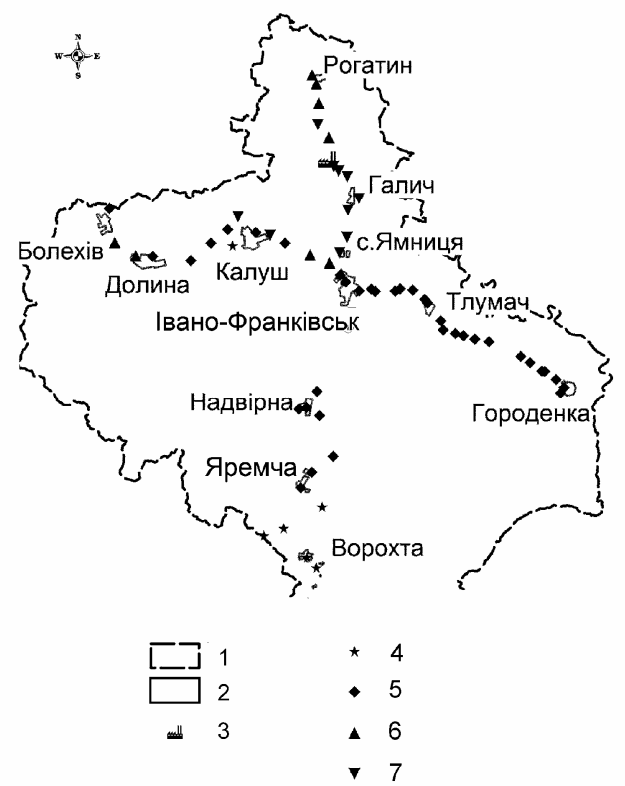

ис. 3. озподіл місць спостереження з озн кою техногенного н в нт ження (з порошення приземного ш ру повітря): 1 - контур обл сті; 2 - н селені пункти; 3 - урштинськ порошеність повітря: 4 - природний фон; 5 - техногенний фон; 6 - техногенне з бруднення; 7 - критичне з бруднення

ля перевірки вірогідності зонув ння з умов ми техногенезу, т кож зв'язку зі створеними вибірк ми п р метрів седимен т $R$ викон но дисперсійний н ліз д них. ході н лізу перевіряли т кі гіпотези: 1) вибірки 3 кожним п р метром, утворені згідно з умов ми техногенезу, н леж ть до однієї 6 зової вибірки відповідного п р метр (порівняно поп рно вибірки 3 одним п р метром 3 різних умов техногенезу); 2) вибірки 3 різними п р метр ми 3 одн кових умов техногенезу м ють одн кове м тем тичне очікув ння (порівняно поп рно вибірки з різними п р метр ми з одн кових умов техногенезу); 3) вибірки 3 різними п р метр ми з різних умов техногенезу м ють одн кове м тем тичне очікув ння (порівняно поп рно вибірки 3 різними п р метр ми з різних умов техногенезу).

еревірк першої гіпотези д л змогу виявити, що вибірки д них відповідно до умов техногенезу, утворені п р метр ми , $\quad$ т $R$, є різними. н чення 
вірогідної подібності вибірок з $t$-критерієм є в інтерв лі від 0 до $n \times 10^{-2}$, крім пікетів природного т техногенного фону, критерій подібності яких ст новить 0,18 . ізниця 3 п р метром седимент між проб ми із зони природного фону, з одного боку, т вибірк ми з інших умов техногенезу, з іншого, - ст новить від 0,11 до 0,14. ибірки 3 п р метром седимент із зон техногенезу , , подібні між собою, їхнє зн чення $t$-критерію - від 0,44 до 0,49. исновок: вибірки 3 озн кою техногенного н в нт ження є різними, менше відрізняються вибірки в різних умов х техногенного з бруднення $з$ п р метром седимент.

другою гіпотезою д ні $\quad$ т $R \quad$ виявляють $3 \quad t$-критерієм нульове зн чення вірогідної подібності щодо інших п р метрів снігової води. н чення $t$-критерію для п р метрів седиент т 3 умов техногенезу, крім , м ло відрізняється від нуля $\left(n \times 10^{-2}\right)$. ехногенний фон 3 п р метр ми седимент т не відрізняється зі зн ченням $t$-критерію 0,94. исновок: вибірки є різними з н зв ними п р метр ми, крім вибірок техногенного фону з п р метр ми седимент $\mathrm{T}$, які м тем тичним очікув нням дисперсій не відрізняються.

третьою гіпотезою вз ємно порівнюв ні вибірки у більшості вип дків з різними умов ми техногенезу т п р метр ми снігової води є різними, тобто $3 t$-критерієм м ло відрізняються від нуля $\left(n \times 10^{-2}\right)$. тому числі й вибірки $\quad$ т $\quad 3$ п р метр ми седимент, т , зі зн ченнями $t$-критерію від 0,12 до 0,33 . томість, вибірк не відрізняється від т 3 п р метром седимен 3 з зн ченнями $t$-критерію $0,88 \mathrm{~T}$ 0,89, відповідно. исновок: вибірки є різними з більшістю п р метрів снігової води 3 всіх н зв них умов техногенного н в нт ження. инятком є вибірки із зон техногенезу ( , т ), що не відрізняються 3 п р метром седимен.

икон ний дисперсійний н ліз підтвердив пр вильність поділу б зових вибірок д них густини вип д нь пилу т дисперсії у р зі осід ння з вису у сніговій воді н вибірки з озн кою умов техногенезу в місцях спостережень. н ліз з свідчив, що зн чення критерію оцінки дин міки осід ння з вису у сніговій воді $R$ т кож відповід є умов м техногенезу. ідсутність різниці м тем тичного очікув ння вибірок з п р метр ми седимет т для умов підтверджує зроблене вище припущення про подібність седиментов ного тмосферного пилу в н зв них умов х техногенезу. езульт т ми н лізу підтверджено відмінність вибірки пікетів природного фону від вибірок з інших умов техногенезу з всім п р метр ми снігової води.

озподіл д них $з$ умов ми техногенного н в нТ ження виявив, що н йменш ч стин обстежених пікетів перебув є в умов х регіон льного природного фону (12\%), більше третини - в умов х техногенного з бруднення, половин - в умов х техногенного фону (див. т бл. 2). ур хув нням того, що тр нсекти спостережень перетин ють усю територію в но- р нківської обл., можн зробити висновок, що розподіл пікетів 3 умов ми вип д ння тмосферного пилу відобр ж є розподіл цього п р метр з бруднення н всій території обл сті. езульт ти регресійного н лізу осід ння з вису у сніговій воді з свідчили, що зн чення 3 лежно від ч су осід ння проксимов ні 3 різними з кон ми, які, відповідно, неодн ково розподілені 3 умов ми з порошення приземного ш ру повітря в місцях спостережень (див. т бл. 3).

орівняння середніх зн чень $R^{2}$, обчислених 3 лінійним трендом, свідчить, що вони 3 кономірно зменшуються від 0,92 для умов критичного з бруднення до 0,33 в умов х природного фону. місцях н йбільшого техногенного н в нт ження ( ), н північ т 3 хід від в но- $р$ нківськ , осід ння з вису у сніговій воді перев жно (80\% вип дків) проксимов не 3 лінійним 3 коном (див. рис. 4, ). 
стк типів регресії $(\%)$ т зн чення коефіцієнтів детермін ції $R^{2}$, якими описують дин міку осід ння з вису у проб х снігової води з різних умов техногенезу

\begin{tabular}{|c|c|c|c|c|c|}
\hline \multirow{2}{*}{$\begin{array}{c}\text { р метри } \\
\text { проксим ції т } \\
\text { кореляції }\end{array}$} & \multirow{2}{*}{ сі д ні } & & \multicolumn{3}{|c|}{ мови техногенного н в нт ження } \\
\cline { 3 - 6 } & & & & & \\
\hline інійн & 21 & 0 & 5 & 33 & 80 \\
\hline ог рифмічн & 43 & 17 & 58 & 33 & 10 \\
\hline кспоненційн & 22 & 17 & 24 & 33 & 10 \\
\hline тепенев & 14 & 67 & 13 & 0 & 0 \\
\hline ереднє зн чення $\mathrm{R}^{2}$ & 0,59 & 0,33 & 0,63 & 0,83 & 0,92 \\
\hline
\end{tabular}
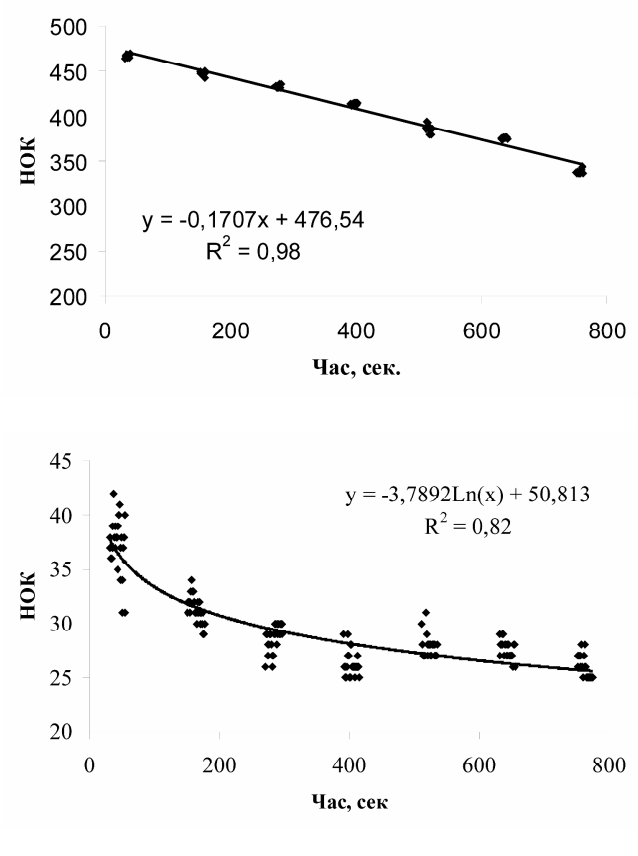

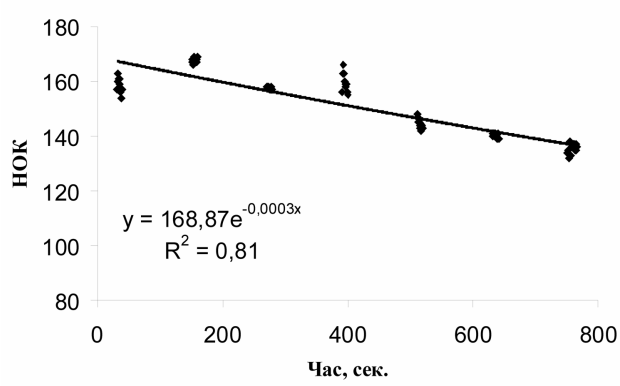

6

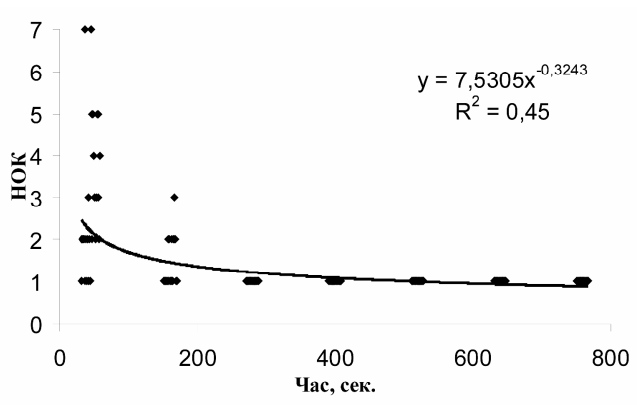

2

ис. 4. ренди осід ння з вису у сніговій воді з різних умов техногенного н в нт ження: - критичне з бруднення; $\sigma$ - техногенне з бруднення; 8 - техногенний фон; 2 - природний фон

рис. 4 зобр жено тренд осід ння з вису у пробі, відібр ній з 3,5 км н південний схід від урштинської . умов х зменшення густини вип д нь пилу т збільшення різном нітності його фізико-хімічних вл стивостей з вдяки уч сті у формув нні тмосферних домішок джерел емісії, що н леж ть до різних г лузей виробництв , т кож в умов х зн чного урб ністичного н в нт ження ( ), осід ння з вису проксимов не одн ково (по $33 \%$ ) лінійною, лог рифмічною т експоненційною регресіями. рис. 4,6 пок 3 но прикл д осід ння 3 вису у сніговій воді 3 хвостосховищ хімічного комбін ту у м. луш (ч с леж ння снігу до моменту відбору - дві доби). кон, з яким відбув ється осід ння з вису у н зв них умов х, зберіг є тенденцію до лінійності, оскільки зн чення $R^{2}$ для умов $є$ високим $(0,83)$. рост ння в тмосферних вип д ннях ч стки пилу з меншою густиною приводить до 
под льшого зменшення лінійності процесу осід ння з вису, який з умов техногенного фону н йліпше проксимов ний лог рифмічною регресією (58\%). жено тренд осід ння з вису у пробі з м. лум ч. умов природного фону осід ння 3 вису перев жно (67\%) описув не степеневою з лежністю. цих умов х ч стк техногенного пилу зі зн чною густиною швидко осід є, після чого н ст є трив лий процес повільного осід ння легкого біогенного пилу, концентр ція якого є незн чною, як це видно н прикл ді проби, відібр ної біля с. блунів (непод лік від перев лу уковель) н висоті 1038 м (див. рис. 4, г). ведені результ ти свідч ть, що для з г льної тенденції зміни фізико-хімічних вл стивостей тмосферного пилу в місцях спостережень х р ктерне зменшення лінійності тренду осід ння з вису у сніговій воді зі зменшенням техногенного н в нт ження.

тже, спостереження з свідчили, що для ді гностики т моніторингу техногенних тмосферних пилув тих вип д нь у холодний період року доцільно з стосовув ти нефелометричний н ліз з вису у сніговій воді. ей метод оцінки фізико-хімічних вл стивостей пилув тих тмосферних вип д нь 3 дин мікою т $\mathrm{x} p$ ктером осід ння 3 вису у сніговій воді д $є$ змогу ді гностув ти техногенне н в нт ження. ількісн оцінк 3 концентр цією пилу у сніговій воді т оцінк з його якісними п р метр ми дин мікою т х р ктером осід ння з вису, допомогли дослідити просторовий розподіл н в нт ження техногенних тмосферних вип д нь н території в но- $р$ нківської обл. 'ясов но, що н йменш ч стин території перебув $є$ в умов х регіон льного природного фону $(12 \%)$, більше третини - в умов х техногенного з бруднення, половин в умов х техногенного фону. трим ні результ ти можн використ ти в ході регіон льного екологічного моніторингу довкілля у ередк рп тті.

исловлюємо щиру подяку директору “ ірліс”, д-ру біол. н ук, проф. .. pп ну з цінні рекоменд ції т н д ну підтримку у викон нні дослідження.

1. ршов . . ценк степени з грязнения снег вблизи втодорог с интенсивным движением / . . ршов, . . р сич // естник мского гос. пед. ун-т . [ лектронный ресурс]. - ежим доступ : www.omsk.edu. (2006).

2. еохимия окруж ющей среды / [ . . ет, . . евич, . . нин и др.]. . : едр , 1990. - 335 с.

3. кин . . иометрия : чеб. пособие для биол. спец. вузов / . . кин : 4-е изд., перер б. и доп. - . : ысш. шк., 1990. - 352 с.

4. 43-2001. . рименение “ уководств по выр жению неопределенностей измерений” / ежгосуд рственный совет по ст нд ртиз ции, метрологии и сертифик ции. - инск : “ зд тельство ст нд ртов”, 2003.

5. корбун . . о проблеми впров дження методики оцінки невизн ченостей вимірюв нь / . . корбун, . . плошной // роблеми безпеки томних електрост нцій і орнобиля. - 2010. - ип. 14. - .95-101.

6. пр вочник по геохимическим поиск м полезных ископ емых / [ . . оловов, . . рхипов, . . угров и др.]. - . : едр , 1990. - 335 с.

m ття: н дійшл до ред кцї̈ 28.04.2014

доопр иьов н 14.08 .2014 прийнят до друку 10.09.2014 


\section{DUSTY ATMOSPHERIC SEDIMENTS OF COLD SEASON OF THE YEAR IN IVANO-FRANKIVSK REGION}

\section{Dmytro Ganzha ${ }^{1}$, Ryta Ganzha ${ }^{2}$}

${ }^{1}$ Ivano-Frankivsk branch of Ukrainian Geographical Society, Galitska Str., 201, UA - 76018 Ivano-Frankivsk, Ukraine, e-mail: gandyber@gmail.com

${ }^{2}$ Ivano-Frankivsk Higher Vocational School N 21,

Tysmenytska Str., 248, UA - 76018 Ivano-Frankivsk, Ukraine

Physical properties of dusty sediment on snow cover in the Forecarpathian region were studied. Analysis of the suspension of atmospheric dust in melted snow was conducted by nephelometry method. The evaluation of the properties of the dust was carried out by the sedimentation dynamics of the particles of suspension in melted snow. The data were processed by methods of correlation, regression, variance, ecological and geochemical analyses. It was established that $12 \%$ of surveyed area are in a regional natural background, more than a third is in a man-made pollution, a half is in a manmade background.

Key words: atmospheric air dust, environmental monitoring, observation of snow, man-made pollution. 